\title{
Erratum to: Suspended solids and total phosphorus loads and their spatial differences in a lake-rich river basin as determined by automatic monitoring network
}

\author{
Jari Koskiaho • Sirkka Tattari • Elina Röman
}

Published online: 24 April 2015

(C) Springer International Publishing Switzerland 2015

Erratum to: Environ Monit Assess (April 2015) 173, Issue 4:4397

DOI 10.1007/s10661-015-4397-6

The original version of this article contained a mistake.

The corrected versions are given below.

In the Abstract, the figures of the annual TP loading from the Karjaanjoki basin should be 11,300 and 23,900 instead of 11,400 and 23,700.

In the Introduction, the area of the referred (Koskiaho et al. 2009) catchment should be $0.12 \mathrm{~km}^{2}$ instead of $0.012 \mathrm{~km}^{2}$.

The online version of the original article can be found at http:// dx.doi.org/10.1007/s10661-015-4397-6.

J. Koskiaho $(\bowtie) \cdot$ S. Tattari $\cdot$ E. Röman

Finnish Environment Institute (SYKE), PO Box 140,

FIN-00251 Helsinki, Finland

e-mail: jari.koskiaho@ymparisto.fi 